Check for updates

Cite this: RSC Adv., 2017, 7, 49423

Received 11th August 2017

Accepted 13th October 2017

DOI: $10.1039 / c 7 r a 08879 e$

rsc.li/rsc-advances

\section{Anti-ulcerogenic effect of KFP-H008 against ethanol-induced gastric ulcer via p38 MAPK/NF- $\kappa B$ pathway}

\author{
Mei Su, $\dagger^{\mathrm{a}}$ Cheng-yuan Li, (D) $\dagger^{\mathrm{b}}$ Lin Zhou, ${ }^{\mathrm{b}}$ Yun-yi Yan, ${ }^{\mathrm{b}}$ Lu-yao Ao, ${ }^{\mathrm{b}}$ Guang-ji Wang, ${ }^{\text {a }}$ \\ Wei-rong Fang ${ }^{\star b}$ and Yun-man Li ${ }^{\star b}$
}

1-(5-(1H-Indol-5-yl)-1-(pyridin-3-ylsulfonyl)-1H-pyrrol-3-yl)-N-methylmethanamine (KFP-H008), a novel potassium-competitive acid blocker developed for the treatment of acid-related diseases, has been reported to inhibit gastric acid secretion effectively, while its effects on gastric ulcer have not been previously explored. The current study aimed to investigate the protective potential of KFP-H0O8 on ethanol-induced gastric ulcer and gastric epithelial cell damage. $0.2 \mathrm{ml}$ absolute ethanol and $5 \%$ ethanol were applied to establish a gastric ulcer model in vivo and in vitro, respectively. In vivo, pre-treatment with KFP-H008 reduced ethanol-induced gastric ulcer index (gross lesions) and histopathological scores (microscopic lesions), and also decreased the expressions of malonaldehyde (MDA), NO and myeloperoxidase (MPO), along with the decline of pro-inflammatory cytokines (TNF- $\alpha, \mathrm{IL}-1 \beta$ and IL-6) or iNOS in tissues and serum. Meanwhile, the levels of superoxide dismutase (SOD) and glutathione (GSH) were both increased. Pre-treatment with KFP-H0O8 also effectively down-regulated the protein expression of $p-p 38$ mitogen-activated protein kinase (MAPK) and p65 nuclear factor- $\mathrm{KB}$ (NF-KB) in ethanol-treated gastric tissues. In vitro, pre-treatment of KFP-H008 promoted the cell viability after challenge of $5 \%$ ethanol, and suppressed the expression of TNF- $\alpha, I L-1 \beta, I L-6$ or iNOS in cell supernatant. Furthermore, the activations of p38 MAPK and NF-KB in GES-1 cells induced by ethanol were reversed by KFP-H008. In all, KFP-H008 presented protective effects against gastric ulcer and the underlying mechanism might be associated with the antioxidant properties and anti-inflammatory status through p38 MAPK/NF-KB pathway.

\section{Introduction}

Gastrointestinal (GI) diseases have now become a global problem which affects millions of people worldwide. Peptic ulcer is the most common multifactor gastrointestinal disorder. ${ }^{1}$ It is widely recognized that excessive alcohol ingestion, serving as the main incentive of gastric ulcer in humans, increases the risk of major upper gastrointestinal bleeding. ${ }^{2}$ Alcohol is one of the most commonly abused agents, thus, we chose the ethanolinduced gastric model to investigate the effects of drugs against peptic ulcer and the potential mechanisms.

The pathogenesis of various GI diseases including peptic ulcers is mainly due to oxidative stress, and excessive generation of reactive oxygen species (ROS) poses a serious problem to

${ }^{a}$ State Key Laboratory of Natural Medicines, School of Pharmacy, China Pharmaceutical University, Nanjing 210009, PR China

${ }^{b}$ State Key Laboratory of Natural Medicines, School of Basic Medicine and Clinical Pharmacy, China Pharmaceutical University, Nanjing 210009, PR China. E-mail: weirongfang@163.com; yunmanlicpu@hotmail.com; Fax:+86 2583271173; Tel: +86 2583271173

$\dagger$ These two authors contributed equally to this work. bodily homeostasis and causes oxidative tissue damage. ${ }^{3}$ ROS is excessive produced in response to cigarette smoking, alcohol consumption, infections, ischemia-reperfusion (I/R) injury and many other factors. A major source of ROS in ethanol-treated gastric tissue is the infiltration of activated neutrophils, which is evaluated by the activity of myeloperoxidase (MPO) and leads to oxidative burst. ${ }^{4}$ Malonaldehyde (MDA) is the product of lipid peroxidation, which leads to the cross-linking polymerization of proteins, nucleic acid and other living macromolecules. ${ }^{5}$ In addition, unnecessary MDA is cytotoxic. Nitric oxide synthase (NOS) is a heme-containing monooxygenase expressed in the GI tract that generates $\mathrm{NO}^{3} \mathrm{NO}$ is involved in gastric mucosal defense as well as injury, it maintains mucosal integrity by regulating gastric mucosal blood flow and barrier function, while it also has deleterious effects. Increased iNOS expression is found in chronic ulcerative colitis and peptic ulcer patients, thus, excessive NO generated by iNOS has immense effects on the pathophysiological conditions of the GI tract. ${ }^{6}$ On the contrary, gastric cells have several endogenous antioxidant enzymes such as superoxide dismutase (SOD) and non-enzyme antioxidants such as glutathione (GSH) to scavenge ROS. 
ROS modulate a number of redox-sensitive signaling pathways including mitogen-activated protein (MAP) kinase. The MAPK signaling pathway also involves in inflammation and distributes in various cells. Suppression of the activation of p38 MAPK is able to alleviate the injury caused by extracellular stimuli. $^{7}$ Nuclear factor- $\kappa \mathrm{B}(\mathrm{NF}-\kappa \mathrm{B})$ can also be activated by oxidative stress and acts as potent redox sensors. In previous study, it has been reported that activated p38 MAPK transferred from cytoplasm to nucleus followed by the activation of NF-кb. ${ }^{8}$ Furthermore, NF- $\kappa \mathrm{B}$ is the classic pro-inflammatory transcription factor containing p50/p65 and $\mathrm{I} \kappa \mathrm{B}$, and controls the transcription of inflammatory cytokines. Activated NF- $\kappa$ B translocates into nucleus and triggers the transcriptional activation of several pro-inflammatory mediators such as tumor necrosis factor- $\alpha$ (TNF- $\alpha)$, interleukin-1 $\beta \quad($ IL-1 $\beta)$ and interleukin-6 (IL-6). ${ }^{9}$

1-(5-(1H-Indol-5-yl)-1-(pyridin-3-ylsulfonyl)-1 $H$-pyrrol-3-yl)- $N$ methylmethanamine (KFP-H008, M: 366.11), a new potassiumcompetitive acid blocker developed for the treatment of acidrelated diseases, is capable to inhibit gastric acid secretion effectively, ${ }^{11}$ while its effects on gastric ulcer has not been previously explored. In this study, we investigated the protective effects and underlying mechanisms of KFP-H008 against ethanol-induced gastric in vivo and in vitro. All experiments were in comparison with lansoprazole (a typical PPI commonly used in clinic) and TAK-438 (1-[5-(2-fluorophenyl)-1-(pyridin-3ylsulfonyl)- $1 H$-pyrrol-3-yl]- $N$-methylmethanamine monofumarate, a P-CAB listed in Japan).

\section{Materials and methods}

\subsection{Chemicals and reagents}

KFP-H008 and TAK-438 were provided by Jiangsu Carefree Pharmaceutical Co., Ltd. (Nanjing, China). Lansoprazole (99.45\% purity) was purchased from Yuancheng Gongchuang Technology Co., Ltd. (Wuhan, China). The enzyme-linked immunosorbent assay (ELISA) kits for TNF- $\alpha$, IL-1 $\beta$ and IL- 6 were purchased from ExCell Biotech (Taicang) Co., Ltd. (Shanghai, China). The enzyme-linked immunosorbent assay (ELISA) kit for iNOS was obtained from Cloud-Clone Corp (Houston, USA). The kits for biochemical analysis of MDA, NO, SOD, GSH and MPO were provided by Jiancheng Bioengineering Institute (Nanjing, China). Anti-phospho-p38 MAPK (Tyr323) and anti-NF-кB p65 were obtained from Beijing Biosynthesis Biotechnology Co., Ltd. (Beijing, China). GAPDH Mouse Monoclonal Antibody (GA1R) was purchased from Applygen Technologies Inc. (Beijing, China). Horseradish peroxidase (HRP)-conjugated goat anti-rabbit was products of Beyotime Institute of Biotechnology (Haimen, China). Goat anti-rabbit IgG/FITC and goat anti-rabbit IgG/Cy3 were obtained from Beijing Biosynthesis Biotechnology Co., Ltd. (Beijing, China). 3-(4,5-Dimethyl thiazol-2-yl)-2,5-diphenyl tetrazolium bromide (MTT) was purchased from Sigma-Aldrich Co. LLC. (USA). Dulbecco's Modified Eagle's Medium (DMEM) was provided by Hyclone (USA). Trypsin was purchased from Amresco (USA) and fetal bovine serum (FBS) was produced by Hangzhou Sijiqing Co., Ltd. (Hangzhou, China). All other reagents were of commercially available analytical grade.

\subsection{Animals and experimental protocol}

All animals were cared for in strict compliance with institutional guidelines of China Pharmaceutical University (Nanjing, China). All experiments were approved by the Institutional Animal Care and Use Committee of China Pharmaceutical University (license number: SYXK (Su) 2016-0011). Furthermore, the European Community guidelines (EEC Directive of 1986: 86/ $609 /$ EEC) were implemented on all the procedures and animal care. All efforts were made to minimize animal suffering and to reduce their number.

Male BALB/c mice weighing 18-22 $\mathrm{g}$ were purchased from Shanghai Jiesijie Experimental Animal Co. Ltd. (Shanghai, China), Production License No. SCXK (Hu) 2013-0006. Animals in this study were housed under a $12 \mathrm{~h}$ light/12 h dark cycle at controlled temperature $\left(22-26^{\circ} \mathrm{C}\right)$ and humidity (40-70\%), with free access to food and water.

Mice were randomly divided into seven groups: control, model, KFP-H008 ( $2 \mathrm{mg} \mathrm{kg}^{-1}, 4 \mathrm{mg} \mathrm{kg}{ }^{-1}$, and $\left.8 \mathrm{mg} \mathrm{kg}^{-1}\right)$, lansoprazole (4 $\left.\mathrm{mg} \mathrm{kg}^{-1}\right)$, TAK-438 $\left(4 \mathrm{mg} \mathrm{kg}^{-1}\right)$. Control group and model group were treated with deionized water. Drugs and vehicle (deionized water) were given orally $(0.1 \mathrm{ml}$ per $10 \mathrm{~g})$ to mice for a period of 3 days. $1 \mathrm{~h}$ after the last administration, mice except the control group were fed orally with $0.2 \mathrm{ml}$ absolute ethanol, while those in control group were provided with normal saline in equivalent volume. $4 \mathrm{~h}$ after induction, blood samples were collected from the retro-orbital plexus of each animal and were centrifuged for $10 \mathrm{~min}$ at $2500 \mathrm{~g}$, the supernatant was stored at $-20{ }^{\circ} \mathrm{C}$ before use. After the mice were sacrificed, the stomach were rapidly removed, then rinsed with ice-cold saline to remove the gastric contents in order to assess the extent of gastric damage. After that, each stomach was dichotomized, one moiety immersed in $10 \%$ formaldehyde for histological evaluation and the other moiety stored at $-80{ }^{\circ} \mathrm{C}$ for biochemical determinations. ${ }^{12}$

\subsection{Determination of gastric ulcer index}

Macroscopic scoring of tissue samples was performed by an observer unaware of the treatment groups. The degree of gastric mucosal damage was evaluated from digital pictures, and was rated for gross pathology according to the ulcer score scales as previously described..$^{13}$ The lesions were scored as follows: (0) no lesions; (1) hyperemic mucosa or up to 3 small patches; (2) erosions between 1-2 $\mathrm{mm}$ in length and $1 \mathrm{~mm}$ in width; (3) erosions between $2-3 \mathrm{~mm}$ in length and $1 \mathrm{~mm}$ in width; (4) erosions between 3-4 $\mathrm{mm}$ in length and $1 \mathrm{~mm}$ in width and so on. The length $(\mathrm{mm})$ and the width $(\mathrm{mm})$ of each band was measured by Vernier caliper. The partial scores were then summed to obtain the final total lesion score for each animal. The inhibition percentage was calculated: $\%$ inhibition $=($ the average of $\left.\operatorname{model}_{\mathrm{UI}}-\operatorname{drug}_{\mathrm{UI}}\right)$ /the average of $\operatorname{model}_{\mathrm{UI}} \times 100 \%$.

\subsection{Histological procedure and assessment}

For histological assessment, the glandular stomach was fixed in $10 \%(\mathrm{~V} / \mathrm{V})$ neutral buffered formalin solution for $24 \mathrm{~h}$, sectioned, and then embedded in paraffin wax, sliced into $3 \mu \mathrm{m}$ 
thicknesses, deparaffinized in xylene and rehydrated in a decreasing concentration gradient of ethanol, and finally stained with hematoxylin-eosin (H\&E). The specimens were examined under a positive biological microscope (BX53, Olympus, USA), and were assessed according to the criteria of Laine and Weinstein. ${ }^{6,9,10}$ Briefly, a $1 \mathrm{~cm}$ segment of each histological section was assessed for epithelial cell loss (score: $0-3$ ), edema in the upper mucosa (score: $0-4$ ), hemorrhagic damage (score: $0-4$ ), and the presence of inflammatory cells (score: $0-3$ ), yielding a maximum total score of 14 . The sections were assessed by an experienced pathologist who was blinded to the treatment.

\subsection{Measurements of SOD, MDA, GSH, NO and MPO levels}

The activity of SOD in stomach tissues or serum was determined using the kits on the basis of the manufacturer's instruction, as well as the measurements of MDA, GSH, NO and MPO, respectively.

\subsection{Immunohistochemical analysis of gastric tissues}

$3 \mu \mathrm{m}$ thick sections of different groups were prepared and immunohistochemistry was performed as previously described. Sections were deparaffinized, rehydrated, and were pre-treated in citrate buffer ( $\mathrm{pH}$ 6.0) in microwave, then cooled to room temperature. Endogenous peroxide was blocked with $3 \% \mathrm{H}_{2} \mathrm{O}_{2}$ for $30 \mathrm{~min}$ at room temperature. Sections were washed with $0.01 \mathrm{M}$ phosphate-buffered saline (PBS), blocked with $10 \%$ goat serum for $15 \mathrm{~min}$ to reduce non-specific antibody-binding and then incubated with the primary antibody (p-p38 MAPK, at a ratio of $1: 300$; p65 NF- $\mathrm{KB}$, at a ratio of $1: 300$ ) at $4{ }^{\circ} \mathrm{C}$ overnight. Sections were then rinsed with $\mathrm{PBS}$, reacted with secondary antibodies and a polymer helper for $20 \mathrm{~min}$ at $37^{\circ} \mathrm{C}$, and followed by PBS and poly-HRP goat-anti-rabbit IgG for $30 \mathrm{~min}$ at $37^{\circ} \mathrm{C}$. Finally, the slides were rewashed with PBS and developed with 3,3'-diaminobenzidine (DBA), followed by counterstaining with hematoxylin. ${ }^{14}$ The specimens were examined under a positive biological microscope (BX53, Olympus, USA), and assessed by Image J $1.50 \mathrm{i}$ (National Institutes of Health, USA).

\subsection{Cell culture and cell viability assay}

Human gastric epithelial cell, GES-1 cell line, was cultured at $37{ }^{\circ} \mathrm{C}$ under $5 \% \mathrm{CO}_{2}$ in DMEM composed of $10 \%$ fetal bovine serum (FBS), $80 \mathrm{U} \mathrm{ml}^{-1}$ of penicillin and $0.08 \mathrm{mg} \mathrm{m}^{-1}$ of streptomycin. GES-1 cells were seeded on a 96-well-plate at a density of $3 \times 10^{4}$ cells per well for $16 \mathrm{~h}$.

To investigate the effects of KFP-H008 on the GES-1 cells, the cells were treated with the vehicle, KFP-H008 $(0.3 \mu \mathrm{M}, 1 \mu \mathrm{M}$, $3 \mu \mathrm{M}, 10 \mu \mathrm{M}, 30 \mu \mathrm{M}, 100 \mu \mathrm{M})$ at $37^{\circ} \mathrm{C}$ and incubated for another $24 \mathrm{~h}$. The old medium was removed and $20 \mu \mathrm{l} 0.5 \mathrm{mg} \mathrm{ml}^{-1}$ MTT was added to each well. $4 \mathrm{~h}$ later, the supernatant was discarded and $150 \mu \mathrm{l}$ DMSO was added to each well. The absorbance value of each well was determined at $490 \mathrm{~nm}$ with a microplate spectrophotometer. ${ }^{5}$

To investigate the effects of KFP-H008 on the ethanol-treated GES-1 cells, the cells were pre-treated with the vehicle, KFP-
H008 $(0.3 \mu \mathrm{M}, 1 \mu \mathrm{M}, 3 \mu \mathrm{M})$, lansoprazole $(1 \mu \mathrm{M})$ and TAK-438 $(1 \mu \mathrm{M})$ at $37{ }^{\circ} \mathrm{C}$ and incubated for another $24 \mathrm{~h}$. After that, $0.5 \%$ ethanol was added and co-incubated at $37{ }^{\circ} \mathrm{C}$ for $24 \mathrm{~h}$, while the control group was challenged with PBS. The GES-1 cell supernatant was harvested for the detection of cytokines, then $20 \mu \mathrm{l} 0.5 \mathrm{mg} \mathrm{ml}^{-1}$ MTT was added to each well. $4 \mathrm{~h}$ later, the supernatant was discarded and $150 \mu \mathrm{l}$ DMSO was added to each well. The absorbance value of each well was determined at $490 \mathrm{~nm}$ with a microplate spectrophotometer. ${ }^{5,15}$

\subsection{Immunofluorescence analysis of GES-1 cells}

GES-1 cells were seeded on glass bottom cell culture dishes at a density of $3 \times 10^{4}$ cells per dish for $16 \mathrm{~h}$, the cells were pretreated with the vehicle, KFP-H008 $(0.3 \mu \mathrm{M}, 1 \mu \mathrm{M}, 3 \mu \mathrm{M})$, lansoprazole $(1 \mu \mathrm{M})$ and TAK- $438(1 \mu \mathrm{M})$ at $37^{\circ} \mathrm{C}$ and incubated for another $24 \mathrm{~h}$. After that, $0.5 \%$ ethanol was added and coincubated at $37^{\circ} \mathrm{C}$ for $24 \mathrm{~h}$, while the control group was challenged with PBS. Then, the supernatant was discarded and fixed with $4 \%$ paraformaldehyde solution for $30 \mathrm{~min}$. The dishes were then rinsed with PBS and incubated in a blocking solution that consisted of $10 \%$ normal goat serum and $0.3 \%$ Triton-X100 in PBS for $2 \mathrm{~h}$ at room temperature. After that, the dishes were incubated overnight at $4{ }^{\circ} \mathrm{C}$ with the primary antibody (p-p38 MAPK, at a ratio of $1: 200$; p65 NF- $\kappa B$, at a ratio of $1: 200$ ). Dishes were rinsed with PBS and incubated with goat antirabbit IgG/FITC and goat anti-rabbit IgG/Cy3, respectively for $2 \mathrm{~h}$ at room temperature, and the nuclei was stained with DAPI.$^{16}$ The stained dishes were examined with laser scanning confocal microscope (Carl Zeiss, Oberkochen, Germany) and images were assessed by Image J 1.50i (National Institutes of Health, USA).

\subsection{Measurement of TNF- $\alpha$, IL-1 $\beta$, IL-6 and iNOS levels}

TNF- $\alpha$, IL-1 $\beta$, IL- 6 and iNOS in gastric tissues, serum and cell supernatant were analyzed by enzyme immunoassays using commercially available reagents on the basis of the manufacturer's instructions.

\subsection{Statistical analysis}

All data in the study were represented as mean \pm S.E.M., calculated by Graphpad Prism 5.0. The differences between groups were analyzed by one-way ANOVA using SPSS (IBM SPSS Statistics v19.0). $P$ values $<0.05$ was considered statistically significant and $P$ values $<0.01$ was considered statistically very significant.

\section{Results}

\subsection{KFP-H008 decreases ethanol-induced gastric lesions in mice}

The model of ethanol-induced experimental gastric injury is a widely used model that seems to cause gastric ulcer. The stomach tissues were removed $4 \mathrm{~h}$ after the absolute ethanol treatment. Extensively visible morphological changes caused by ethanol (including mucosal erosion, ulcers, linear hemorrhages, mucosal erythema and edema) were observed in the model 
group as compared to the control group (Fig. 1A), no macroscopic lesions were observed in control group. The mice pretreated with KFP-H008 (4 mg kg ${ }^{-1}$ and $8 \mathrm{mg} \mathrm{kg}^{-1}$ ), lansoprazole $\left(4 \mathrm{mg} \mathrm{kg}^{-1}\right)$ and TAK-438 $\left(4 \mathrm{mg} \mathrm{kg}^{-1}\right)$ significantly reduced areas of gastric ulcer formation compared with the model group $(P<0.01$, Fig. 1B). KFP-H008 inhibited the gastric injury in a dose-dependent manner. The \% inhibition of each drug at different dosages is KFP-H008 $8 \mathrm{mg} \mathrm{kg}^{-1}(72.81 \%)>$ lansoprazole $4 \mathrm{mg} \mathrm{kg}^{-1}(56.61 \%)>\mathrm{KFP}-\mathrm{H} 0084 \mathrm{mg} \mathrm{kg}^{-1}(51.59 \%)>$ TAK$4384 \mathrm{mg} \mathrm{kg}^{-1}(48.42 \%)>$ KFP-H008 $2 \mathrm{mg} \mathrm{kg}^{-1}$ (23.28\%), the \% inhibition of KFP-H008 at $8 \mathrm{mg} \mathrm{kg}^{-1}$ was the highest (Fig. 1C).

\subsection{KFP-H008 decreases the histopathological scores of gastric tissues in mice}

Histological evaluations of gastric walls in ethanol-treated mice had manifested certain extensive damages to the gastric mucosa, edema, leucocytes infiltration, confluent necrosis and a disorganizing cell process (Fig. 2B) compared with the control group (Fig. 2A). Pre-treatment with KFP-H008, lansoprazole and TAK-438 for 3 days protected the gastric mucosa as seen by the reduction in ulcer area, edema, and leucocytes infiltration (Fig. 2C-G), as well as the reduction in histopathological scores (Fig. 2H). KFP-H008 at dose of $2 \mathrm{mg} \mathrm{kg}^{-1}$ apparently suppressed the gastric lesions $(P<0.05)$. KFP-H008 at dosages of $4 \mathrm{mg} \mathrm{kg}^{-1}$ and $8 \mathrm{mg} \mathrm{kg}^{-1}$, lansoprazole $4 \mathrm{mg} \mathrm{kg}^{-1}$ and TAK-438 $4 \mathrm{mg} \mathrm{kg}^{-1}$ all significantly alleviated mucosal damage $(P<0.01)$.

\subsection{KFP-H008 increases SOD, GSH activity and suppresses MDA, NO, MPO level in gastric tissues and serum}

SOD, MDA and GSH are critical indexes of lipid peroxidation. It has been widely accepted that in the digestive system, excessive
NO produced by inducible NO synthase (iNOS) is cytotoxic. MPO is a key marker of neutrophil infiltration into the gastric mucosa.

In gastric tissues, administration of ethanol significantly decreased the expressions of SOD, MDA $(P<0.01)$, while increased MDA, NO and MPO $(P<0.01)$ versus the control group. By contrast, pre-treatment of KFP-H008 presented dosedependent response. KFP-H008 at all the dosages reversed the reduction of SOD apparently $(P<0.01$, Fig. 3A). KFP-H008 at $8 \mathrm{mg} \mathrm{kg}^{-1}$ showed strong inhibitory effects on MDA $(P<0.01$, Fig. 3B). Administration of KFP-H008 at $4 \mathrm{mg} \mathrm{kg}^{-1}$ and $8 \mathrm{mg} \mathrm{kg}^{-1}$ promoted the expression of GSH significantly $(P<0.01)$ and $4 \mathrm{mg} \mathrm{kg}^{-1}$ of KFP-H008 exhibited a more potent effect on the increase of GSH than $4 \mathrm{mg} \mathrm{kg}^{-1}$ of TAK-438 $(P<0.01$, Fig. 3C). KFP-H008 at all the dosages presented significant inhibitory effects on NO and MPO (Fig. 3D and E), and the effects of KFPH008 $4 \mathrm{mg} \mathrm{kg}^{-1}$ on MPO was stronger than lansoprazole (Fig. 3E).

In serum, the levels of MDA $(13.33 \pm 1.44), \mathrm{NO}(11.05 \pm 0.30)$ and MPO (188.46 \pm 0.33$)$ in the ethanol-induced model group were 2.13-fold, 6.30-fold, 2.71-fold stronger than those of control group (MDA 6.25 \pm 0.16 , NO $1.75 \pm 0.46$, MPO $69.49 \pm$ $0.57)$, while its SOD activity (73.64 \pm 2.48$)$ and GSH activity $(57.26 \pm 10.39)$ declined to $42.34 \pm 1.70$ and $7.26 \pm 0.43$, respectively (Fig. 3F-J). Treatment with KFP-H008 showed dosedependent response. Administration of KFP-H008 $\left(4 \mathrm{mg} \mathrm{kg}^{-1}\right.$ and $8 \mathrm{mg} \mathrm{kg}^{-1}$ ) remarkably increased the expression of SOD in serum $(P<0.01$, Fig. 3F) and significantly inhibited MDA level $\left(P<0.01\right.$, Fig. 3G). Furthermore, KFP-H008 $\left(4 \mathrm{mg} \mathrm{kg}^{-1}\right.$ and $\left.8 \mathrm{mg} \mathrm{kg}{ }^{-1}\right)$ exhibited strong inhibitory effects on ethanolinduced NO in serum apparently $(P<0.05$, Fig. 3I), and all the
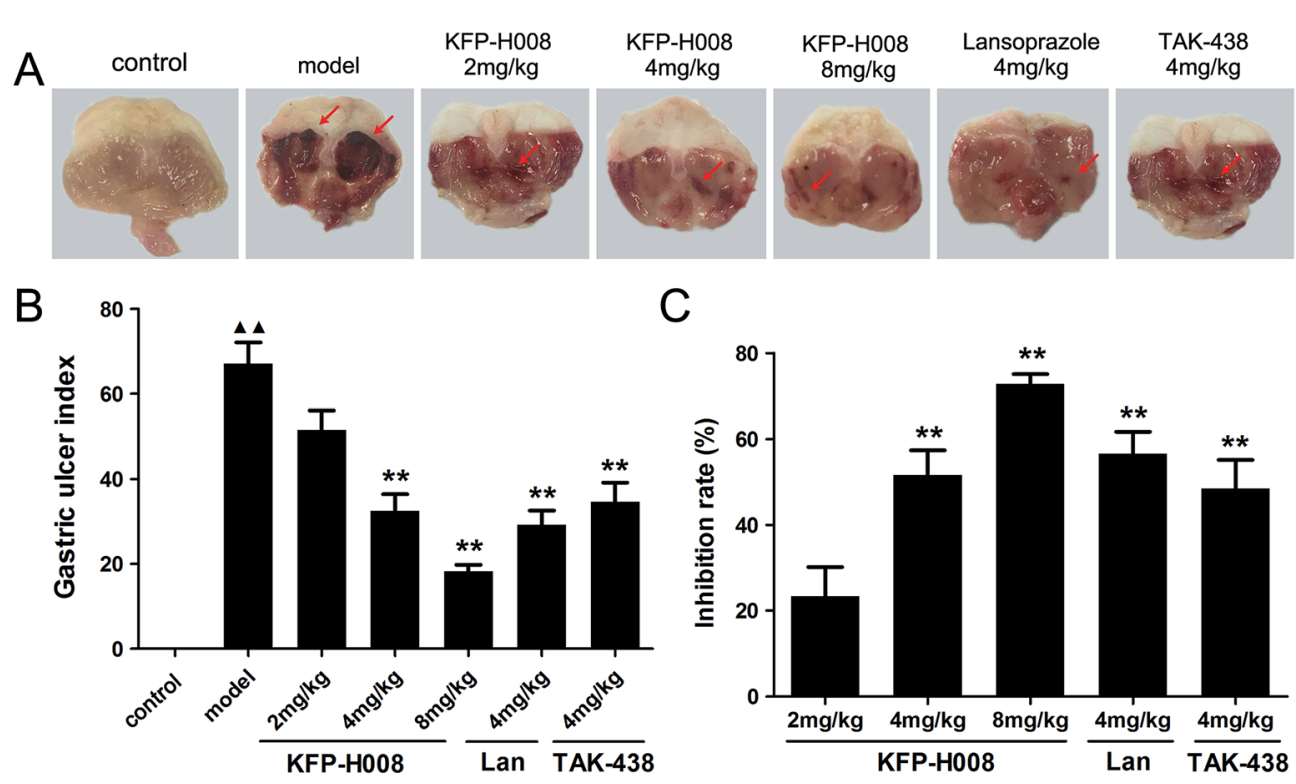

Fig. 1 Effects of KFP-H008 on the ulcer index in ethanol-induced gastric ulcer model. (A) Macroscopic morphology of the gastric mucosa of mice challenged with ethanol. The vehicle, KFP-H008, lansoprazole and TAK-438 were administrated orally $(0.1 \mathrm{ml}$ per $10 \mathrm{~g})$ for a period of 3 days. $1 \mathrm{~h}$ after the last administration, mice except the control group were fed orally with $0.2 \mathrm{ml}$ absolute ethanol and the stomach were removed $4 \mathrm{~h}$ later. (B) The mean gastric ulcer index of each group. $n=10$. (C) $\%$ inhibition $=$ (average of model $\mathrm{UI}_{\mathrm{I}}-$ drugul $\left._{\mathrm{UI}}\right) / \mathrm{average} \mathrm{of} \mathrm{model}_{\mathrm{UI}} \times 100 \%$. $n=8$. Each column represents the mean \pm S.E.M. $\mathbf{\Delta} \boldsymbol{\Delta}, P<0.01$ versus control group. $* *, P<0.01$ versus model group. 

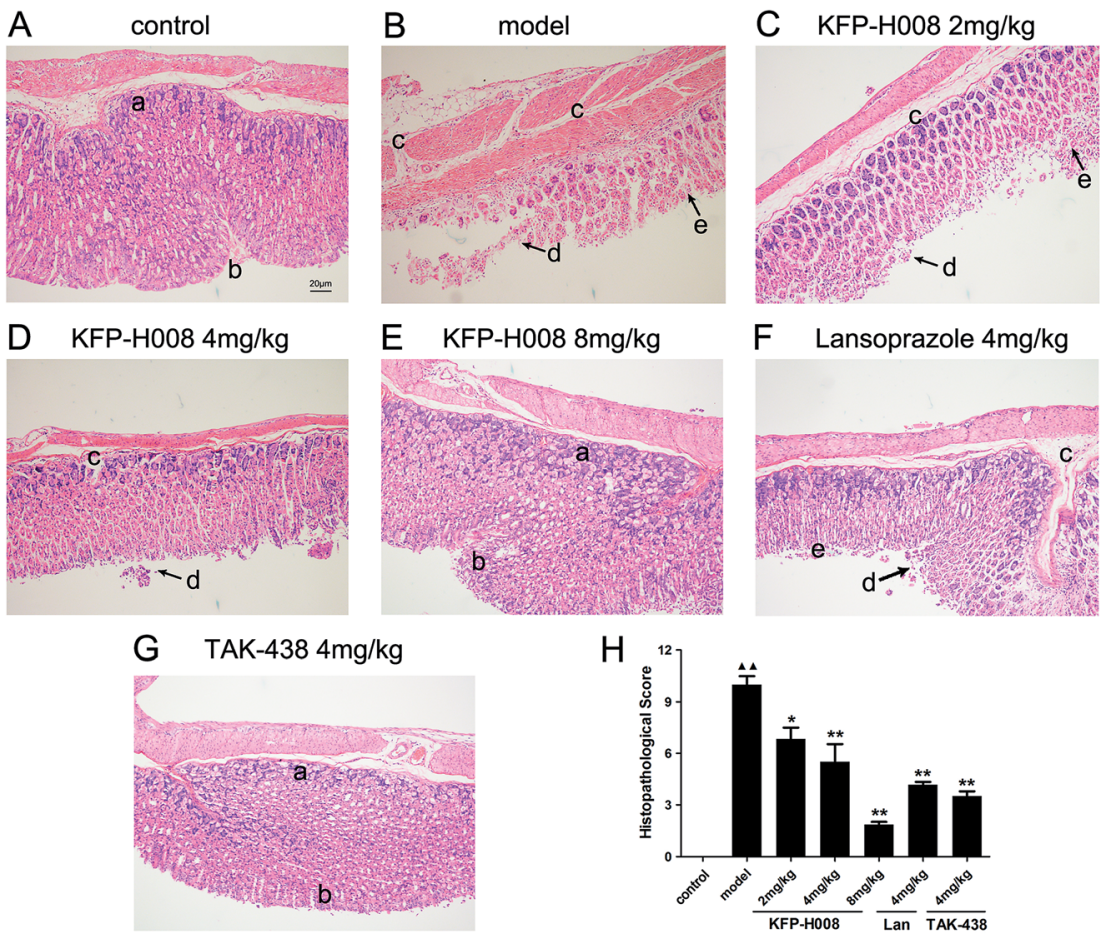

Fig. 2 Effects of KFP-H008 on histopathological lesions in absolute ethanol-induced gastric injury in mice. Histological sections were stained with H\&E (magnification $\times 100$ ). Scale bar $=20 \mu \mathrm{m}$. (A) The control group. (B) Model - absolute ethanol treatment. (C) Ethanol $+\mathrm{KFP}-\mathrm{HO0} 8$ $2 \mathrm{mg} \mathrm{kg}^{-1}$. (D) Ethanol + KFP-H008 $4 \mathrm{mg} \mathrm{kg}^{-1}$. (E) Ethanol $+\mathrm{KFP}-\mathrm{H} 0088 \mathrm{mg} \mathrm{kg}^{-1}$. (F) Ethanol + lansoprazole $4 \mathrm{mg} \mathrm{kg}^{-1}$. (G) Ethanol $+\mathrm{TAK}^{-438}$ $4 \mathrm{mg} \mathrm{kg}^{-1}$. (a) Gland cell, (b) epithelial cell, (c) extensive edema and leucocytes infiltration of sub-mucosa, (d) confluent necrosis on margin zone, (e) the alignment of the glands is distorted in the apical portion. $(\mathrm{H})$ The mean histopathological score of each group. $n=3$. Each column represents the mean \pm S.E.M. $\mathbf{\Delta} \mathbf{\Delta}, P<0.01$ versus control group. $*, P<0.05, * *, P<0.01$ versus model group.

doses of KFP-H008 decreased MPO level in serum remarkably $(P<0.05$, Fig. 3J) versus the model group.

\subsection{KFP-H008 decreases the expressions of TNF- $\alpha$, IL-1 $\beta$, IL- 6 and iNOS in gastric tissues and serum in mice}

Previous studies indicate that oxidative stress triggers transcriptional up-regulation of pro-inflammatory cytokines, such as TNF- $\alpha$, IL-1 $\beta$ and IL-6. Besides cytokine regulation, administration of ethanol apparently increased the level of proinflammatory cytokines TNF- $\alpha$, IL- $1 \beta$ and IL- 6 in both gastric tissues and serum $(P<0.01$, Fig. $4 \mathrm{~A}-\mathrm{F})$.

In gastric tissues, KFP-H008 at dosages of $4 \mathrm{mg} \mathrm{kg}^{-1}$ and $8 \mathrm{mg} \mathrm{kg}{ }^{-1}$ could significantly suppressed the expression of TNF$\alpha$, IL-1 $\beta$ and IL-6 $(P<0.01$, Fig. $4 \mathrm{~A}-\mathrm{C})$, and the inhibitory effects of KFP-H008 were in a dose-dependent manner. At the same time, KFP-H008 at $2 \mathrm{mg} \mathrm{kg}^{-1}$ represented an apparent inhibitory effect on IL-1 $\beta$ in gastric tissues (Fig. 4B). Both KFP-H008 at dosages of $4 \mathrm{mg} \mathrm{kg}^{-1}$ and $8 \mathrm{mg} \mathrm{kg}^{-1}$ showed stronger inhibitory effects on the pro-inflammatory cytokines than lansoprazole $4 \mathrm{mg} \mathrm{kg}^{-1}$ or TAK-438 $4 \mathrm{mg} \mathrm{kg}^{-1}$ in gastric tissues.

In serum, all the dosages of KFP-H008 could alleviate ethanol-induced increase of TNF- $\alpha$ and IL-6 significantly $\left(P<0.01\right.$, Fig. 4D and F). KFP-H008 at both dosages of $4 \mathrm{mg} \mathrm{kg}^{-1}$ and $8 \mathrm{mg} \mathrm{kg}^{-1}$ suppressed the expression of IL-1 $\beta$ apparently $(P<0.05$, Fig. 4E).
NF-KB has also been related to the expression of iNOS and the release of NO. As shown in Fig. 4G and H, administration of ethanol could promote the expression of iNOS in both gastric tissues and serum compared with the control model $(P<0.05)$. While KFP-H008 could reverse the increase of iNOS, and KFPH008 $\left(8 \mathrm{mg} \mathrm{kg}^{-1}\right)$ showed a stronger inhibitory effect on iNOS than lansoprazole $\left(4 \mathrm{mg} \mathrm{kg}^{-1}\right)$ and TAK-438 $\left(4 \mathrm{mg} \mathrm{kg}^{-1}\right)$.

\subsection{KFP-H008 suppresses the activation of $\mathrm{p} 38$ MAPK/NF- $\mathrm{KB}$ signaling in gastric tissues}

To further determine the damage mechanism, the protein expression of p-p38 MAPK (Fig. 5A) and p65 NF-кB (Fig. 5B) were measured by immunohistochemistry. The mitogen-activated protein kinase (MAPK) signaling pathway is involved in inflammation and NF- $\kappa$ B is a classic pro-inflammatory transcription factor. Activated p38 MAPK in cytoplasm would acti-

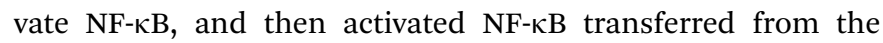
cytoplasm to nucleus and in turn activate p38 MAPK in nucleus. Immunohistochemistry results showed that the expression of p-p38 MAPK or p65 NF- $\mathrm{BB}$ in the model group was distinctly elevated compared with the control group $(P<0.01$, Fig. $5 \mathrm{C}$ and D). KFP-H008 suppressed the expression of p-p38 MAPK and p65 NF- $\mathrm{KB}$ in a dose-dependent manner, and KFP-H008 at all dosages could inhibit the activation of p38 MAPK significantly $\left(P<0.01\right.$, Fig. 5C). KFP-H008 at dosages of $4 \mathrm{mg} \mathrm{kg}^{-1}$ and 

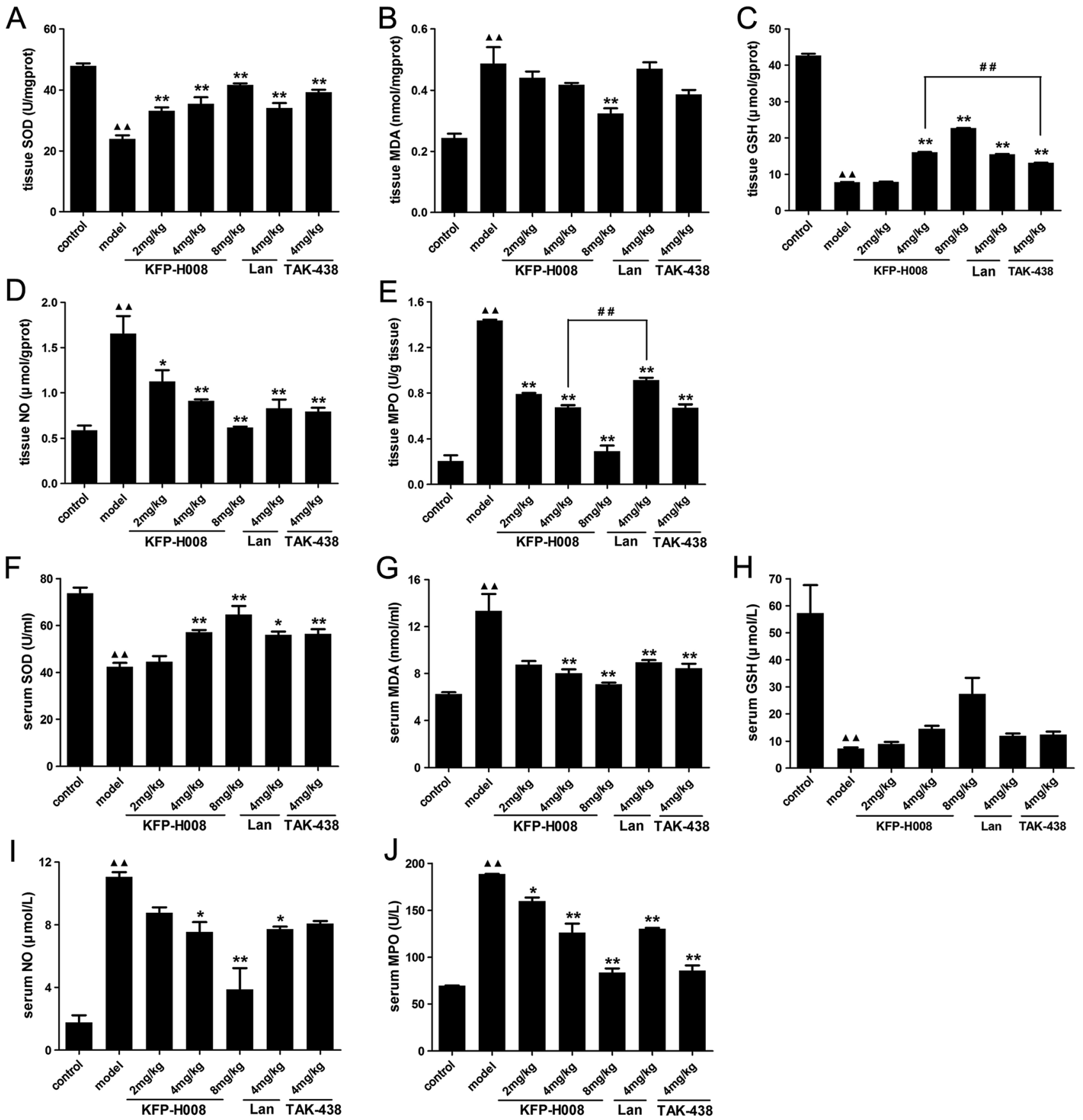

Fig. 3 Effects of KFP-H0O8 on SOD, MDA, GSH, NO and MPO activity in stomach tissues (A-E) and serum (F-J) of ethanol-treated mice. The vehicle, KFP-H008, lansoprazole and TAK-438 were administrated orally $(0.1 \mathrm{ml}$ per $10 \mathrm{~g})$ for a period of 3 days. $1 \mathrm{~h}$ after the last administration, mice except the control group were fed orally with $0.2 \mathrm{ml}$ absolute ethanol and were killed at $4 \mathrm{~h}$ after ethanol challenge. The serum and stomach tissues were collected for biochemical determinations. $n=3$. Each column represents the mean \pm S.E.M. $\mathbf{\Delta} \boldsymbol{\Delta}, P<0.01$ versus control group. * $P<0.05$, **,$P<0.01$ versus model group. \#\#, $P<0.01$ versus KFP-H008 $4 \mathrm{mg} \mathrm{kg}^{-1}$ group.

$8 \mathrm{mg} \mathrm{kg}{ }^{-1}$ could also alleviate the up-regulation of p65 NF- $\kappa \mathrm{B}$ induced by p-p38 $(P<0.01$, Fig. 5D).

3.6. KFP-H008 increases the cell viability in $5 \%$ ethanoltreated GES-1 cells

As shown in Fig. 6A, KFP-H008 at dosages of $0.3 \mu \mathrm{M}, 1 \mu \mathrm{M}, 3 \mu \mathrm{M}$ and $10 \mu \mathrm{M}$ did not show any effects on the cell viability versus the vehicle group, so we chose the doses of $0.3 \mu \mathrm{M}, 1 \mu \mathrm{M}$ and
$3 \mu \mathrm{M}$ to measure the effects of drugs on the cell viability in $5 \%$ ethanol-treated GES- 1 cells. $24 \mathrm{~h}$ after treatment of $5 \%$ ethanol, GES-1 cell viability decreased to $54.46 \%(P<0.01$, Fig. 6B). Pretreatment of KFP-H008 $(0.3 \mu \mathrm{M}, 1 \mu \mathrm{M}, 3 \mu \mathrm{M})$ effectively promoted the viability to $67.97 \%, 79.29 \%$ and $82.09 \%$, respectively. Lansoprazole and TAK-438 could also increase the cell viability after $5 \%$ ethanol treatment apparently $(P<0.05$, Fig. 6B). 

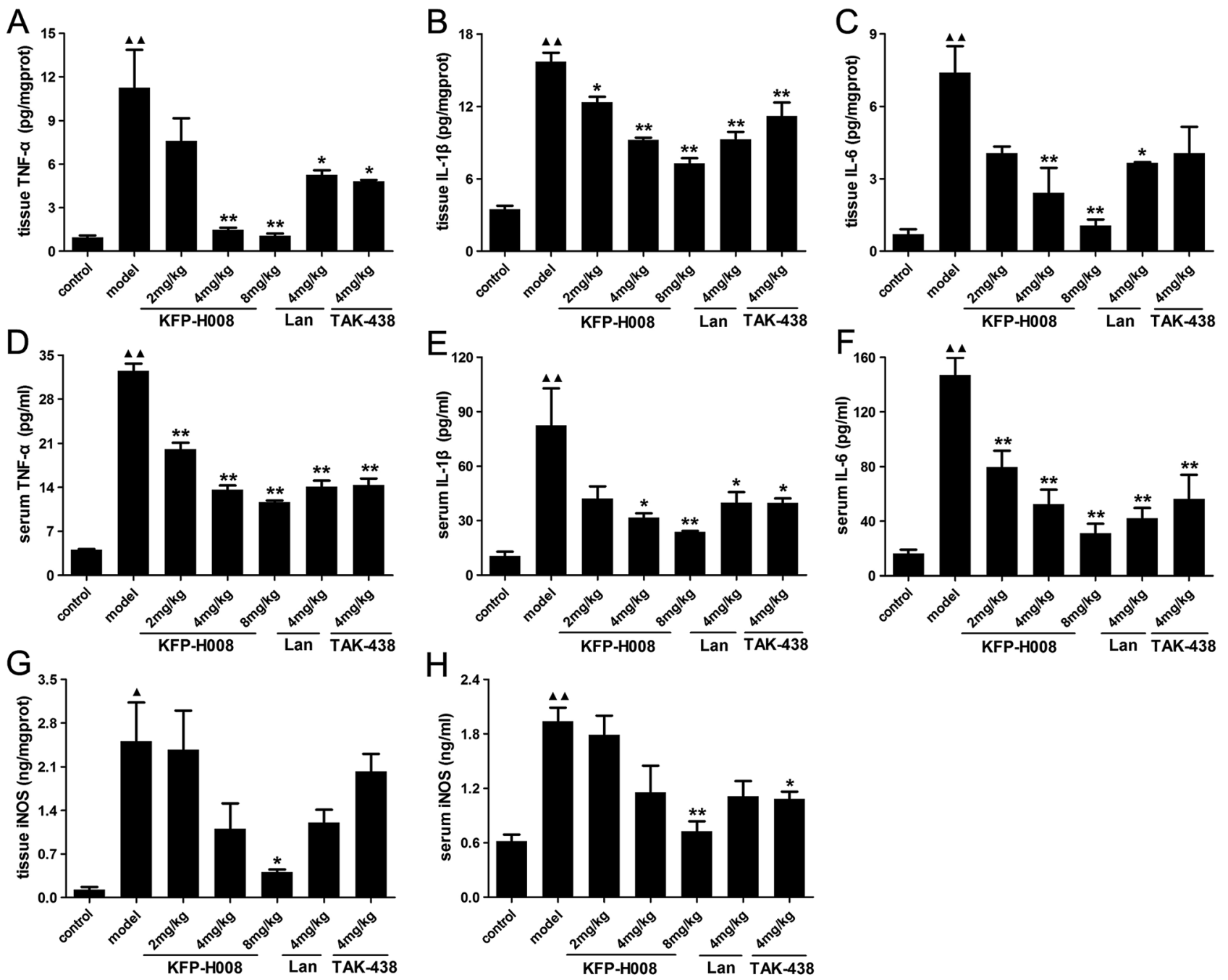

Fig. 4 Effects of KFP-H008 on TNF- $\alpha, I L-1 \beta, I L-6$ and iNOS levels in stomach tissues (A, B, C, G) and serum (D, E, F, H) in mice challenged with absolute ethanol. The vehicle, KFP-H008, lansoprazole and TAK-438 were administrated orally $(0.1 \mathrm{ml}$ per $10 \mathrm{~g})$ for a period of 3 days. $1 \mathrm{~h}$ after the last administration, mice except the control group were fed orally with $0.2 \mathrm{ml}$ absolute ethanol and were killed at $4 \mathrm{~h}$ after ethanol challenge. The serum and stomach tissues were collected for biochemical determinations. $n=3$. Each column represents the mean $\pm \mathrm{S}$.E.M. $\boldsymbol{\Delta}, P<0.05, \boldsymbol{\Delta} \boldsymbol{\Delta}, P$ $<0.01$ versus control group. *, $P<0.05, * *, P<0.01$ versus model group.

3.7. KFP-H008 decreases $5 \%$ ethanol-induced expressions of TNF- $\alpha$, IL-1 $\beta$, IL-6 and iNOS in GES-1 cells

At last, we detected the levels of TNF- $\alpha$, IL-1 $\beta$, IL-6 and iNOS in cell supernatant to confirm the anti-inflammatory and antioxidant properties of KFP-H008. The levels of these cytokines in cell supernatant were dramatically increased in the model group compared with the control group $(P<0.01$, Fig. 7A, B and D; $P<0.05$, Fig. 7C). KFP-H008 at $0.3 \mu \mathrm{M}$ reversed the increases of IL-1 $\beta$ and iNOS significantly $(P<0.01$, Fig. 7B and D). KFP-H008 at dosages of $1 \mu \mathrm{M}$ and $3 \mu \mathrm{M}$ effectively down-regulated all of the cytokine levels in cell supernatant and the inhibitory effects were in a dose-dependent manner $(P<0.05$, Fig. 7A-D). The effects of KFP-H008, lansoprazole and TAK-438 were similar and KFP-H008 of $3 \mu \mathrm{M}$ was considered to be the most significant among three doses.
3.8. KFP-H008 suppresses the expressions of p-p38 MAPK and p65 NF- $\kappa$ B in $5 \%$ ethanol-treated GES-1 cells

In vitro, the mechanism of protective effect of KFP-H008 on 5\% ethanol-induced cell damage was detected by immunofluorescence. We assessed the expressions of p-p38 MAPK and p65 $\mathrm{NF}-\kappa \mathrm{B}$. The red, blue and green staining represents p-p38 MAPK, DAPI and p65 NF- $\kappa$ B, respectively (Fig. 8A and B). After challenge of $5 \%$ ethanol in cells, p38 MAPK and NF- $\kappa$ B were activated, the fluorescence density of p-p38 MAPK and p65 NF- $\kappa \mathrm{B}$ increased remarkably versus the control group $(P<0.01$, Fig. 8C and D). On the contrary, KFP-H008 reversed the ethanolinduced expressions of p-p38 MAPK and p65 NF- $\mathrm{B}$ in a concentration-dependent manner. Furthermore, KFP-H008 at $1 \mu \mathrm{M}$ effectively decreased the fluorescence density of p-p38 MAPK and p65 NF- $\kappa$ B in ethanol-treated GES-1 cells $(P<0.05$, Fig. 8C and D). 

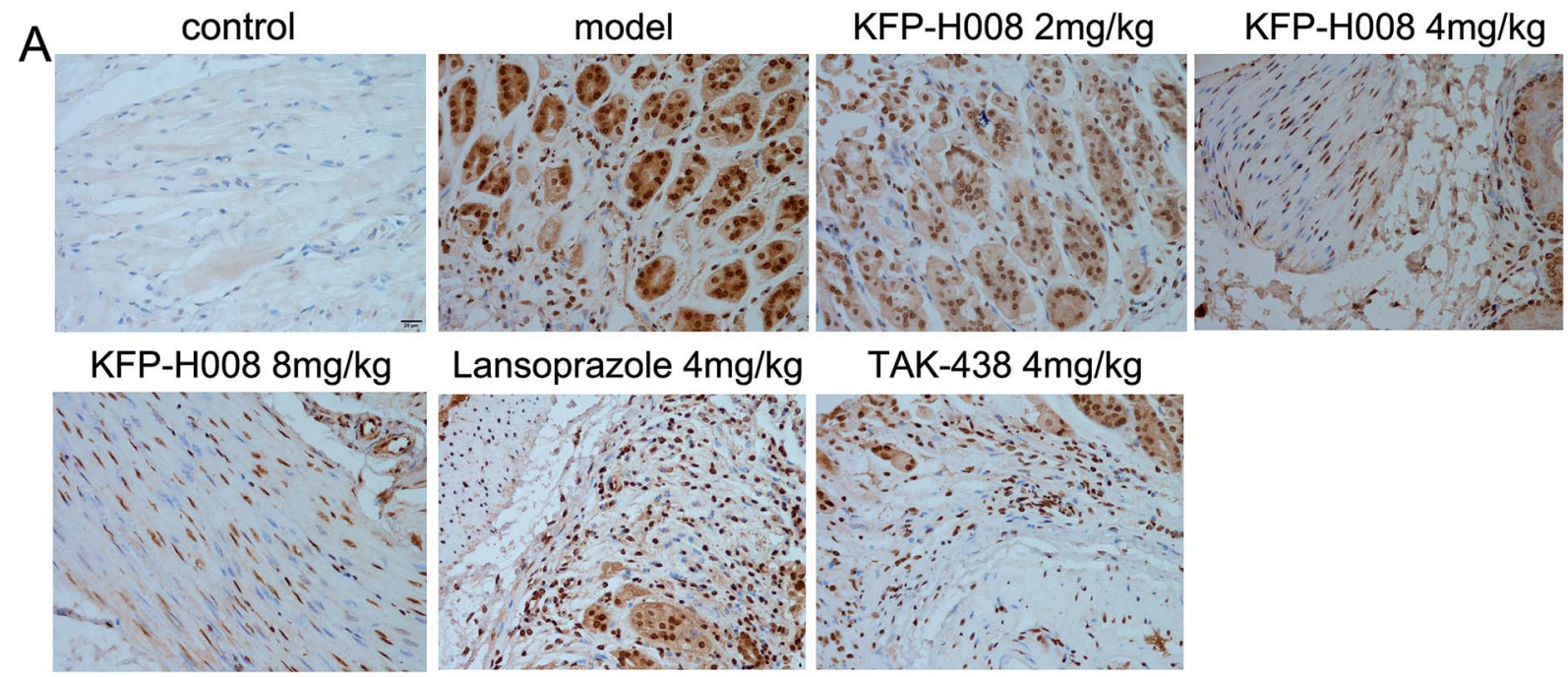

TAK-438 4mg/kg

B
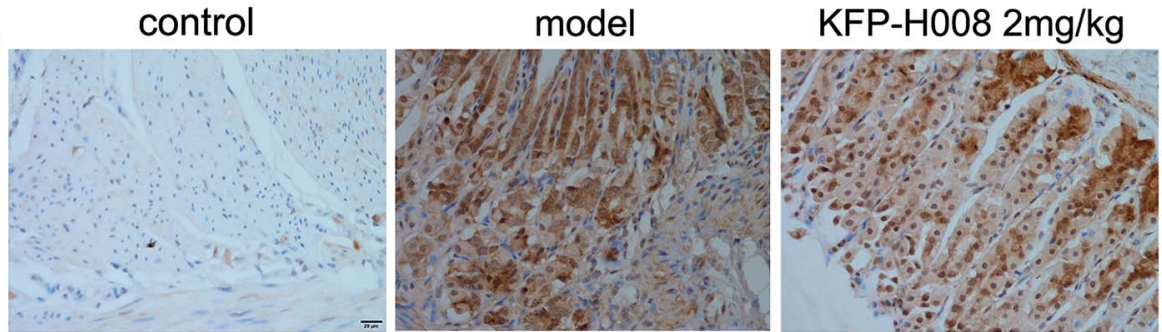

KFP-H008 4mg/kg

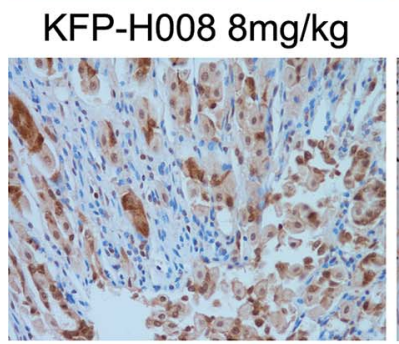

Lansoprazole $4 \mathrm{mg} / \mathrm{kg}$
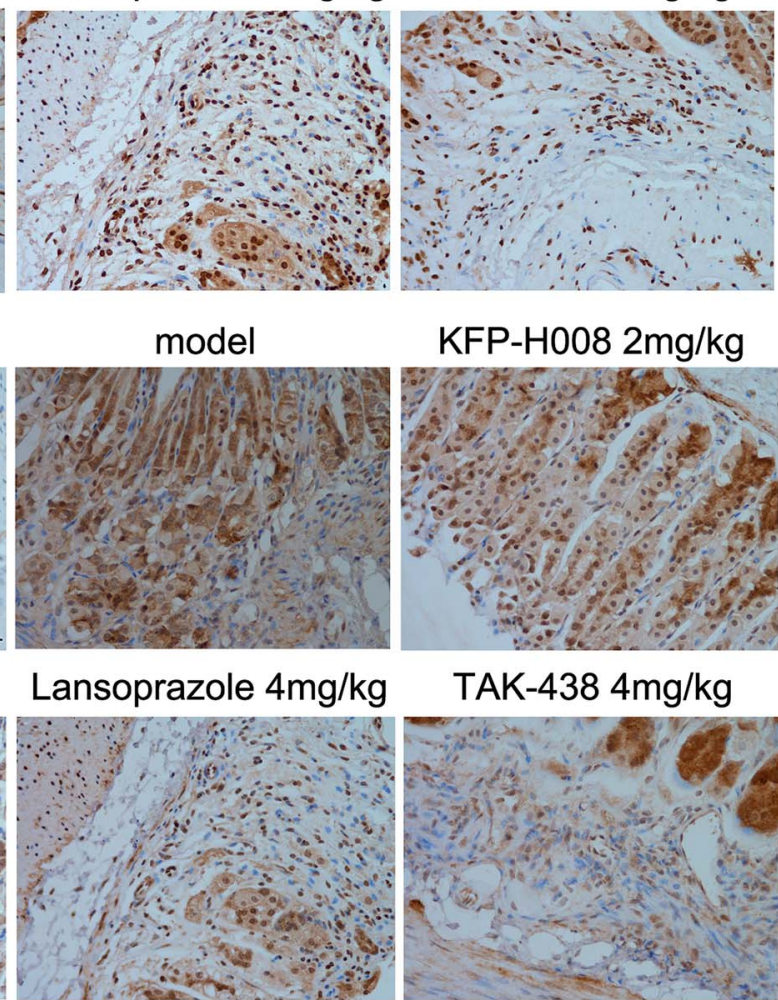

\section{TAK-438 4mg/kg}

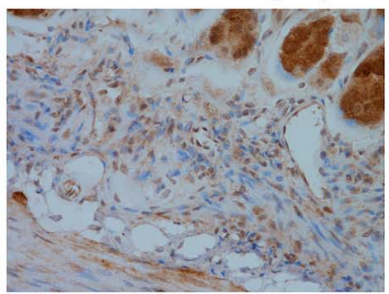

C
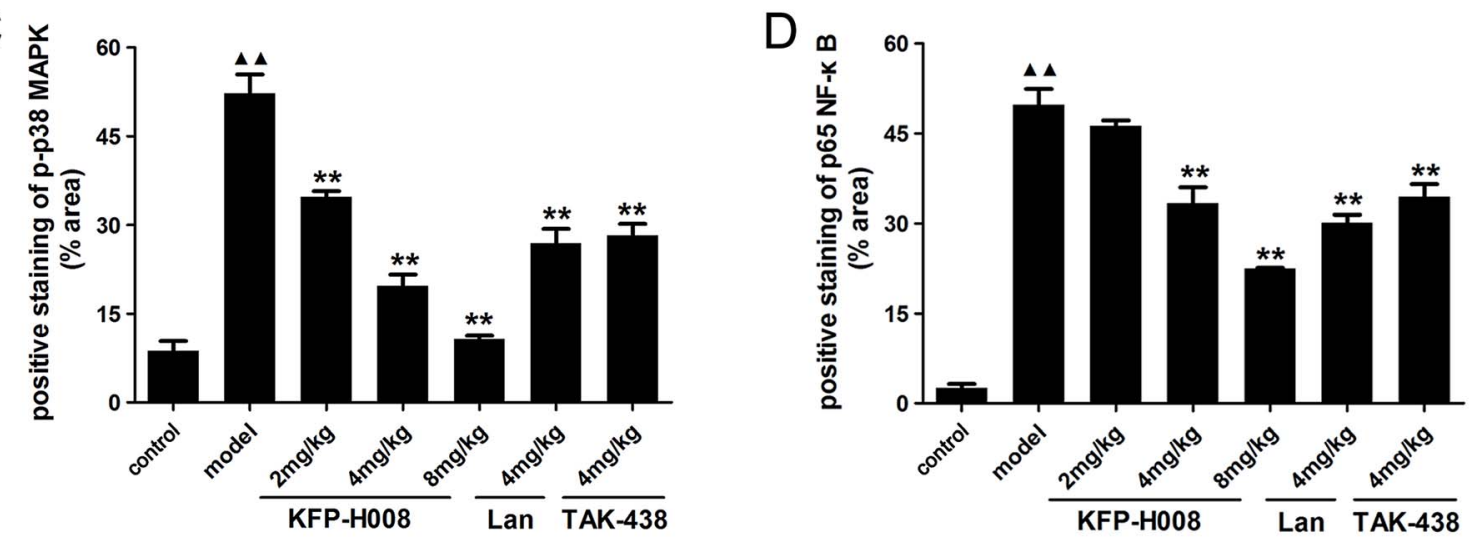

Fig. 5 Effects of KFP-H008 on the expression of p38 MAPK/NF- $\kappa B$ signaling-related proteins in ethanol-induced gastric ulcer model in mice. Representative photomicrographs of immunohistochemical staining showed the effects of KFP-H008 on p-p38 MAPK (A) and p65 NF- $\mathrm{B}$ (B) immunoreactivity in gastric mucosa. All the photographs were taken at $400 \times$. Scale bar $=20 \mu \mathrm{m}$. (C) The positive staining of $p$-p38 MAPK (\%

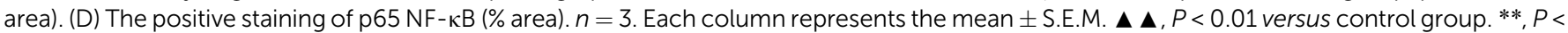
0.01 versus model group. 

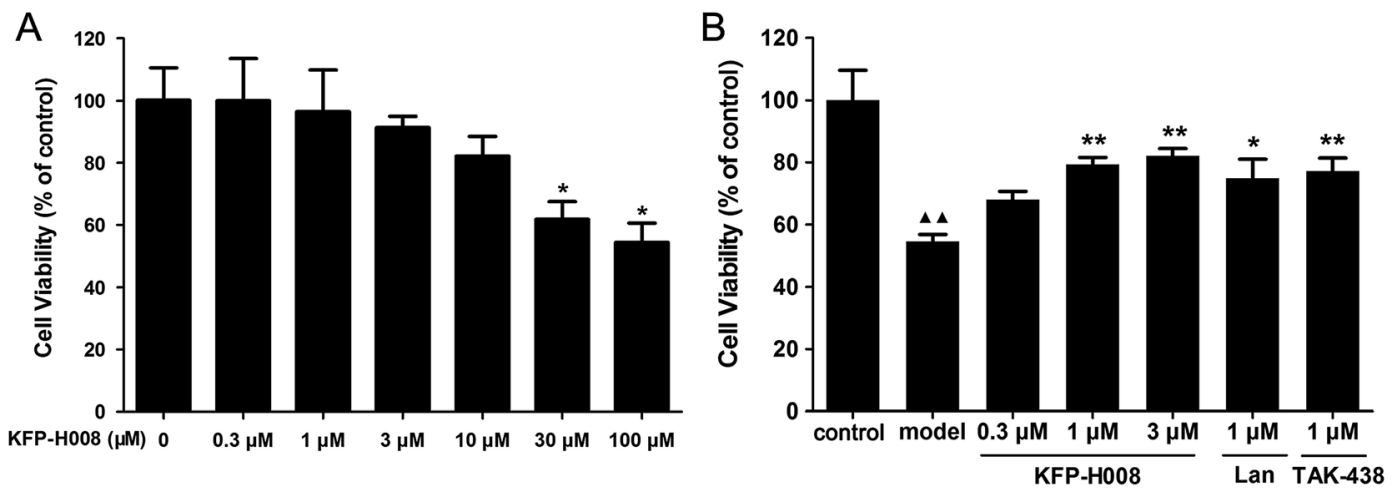

Fig. 6 Effects of KFP-H008 on cell viability. (A) GES-1 cells were treated with KFP-H008 of different concentrations $(0,0.3 \mu \mathrm{M}, 1 \mu \mathrm{M}, 3 \mu \mathrm{M}, 10 \mu \mathrm{M}$, $30 \mu \mathrm{M}, 100 \mu \mathrm{M})$ for $24 \mathrm{~h}$ and then the cell viability were evaluated by MTT assay. (B) GES-1 cells were pretreated with the vehicle, KFP-H008, lansoprazole and TAK-438 for $24 \mathrm{~h}$, followed by exposure to $5 \%$ ethanol for $24 \mathrm{~h}$, then the cell viability were tested by MTT assay. $n=3$. Each column represents the mean \pm S.E.M. $\mathbf{\Delta} \Delta, P<0.01$ versus control group. ${ }^{*}, P<0.05, * *, P<0.01$ versus model group.
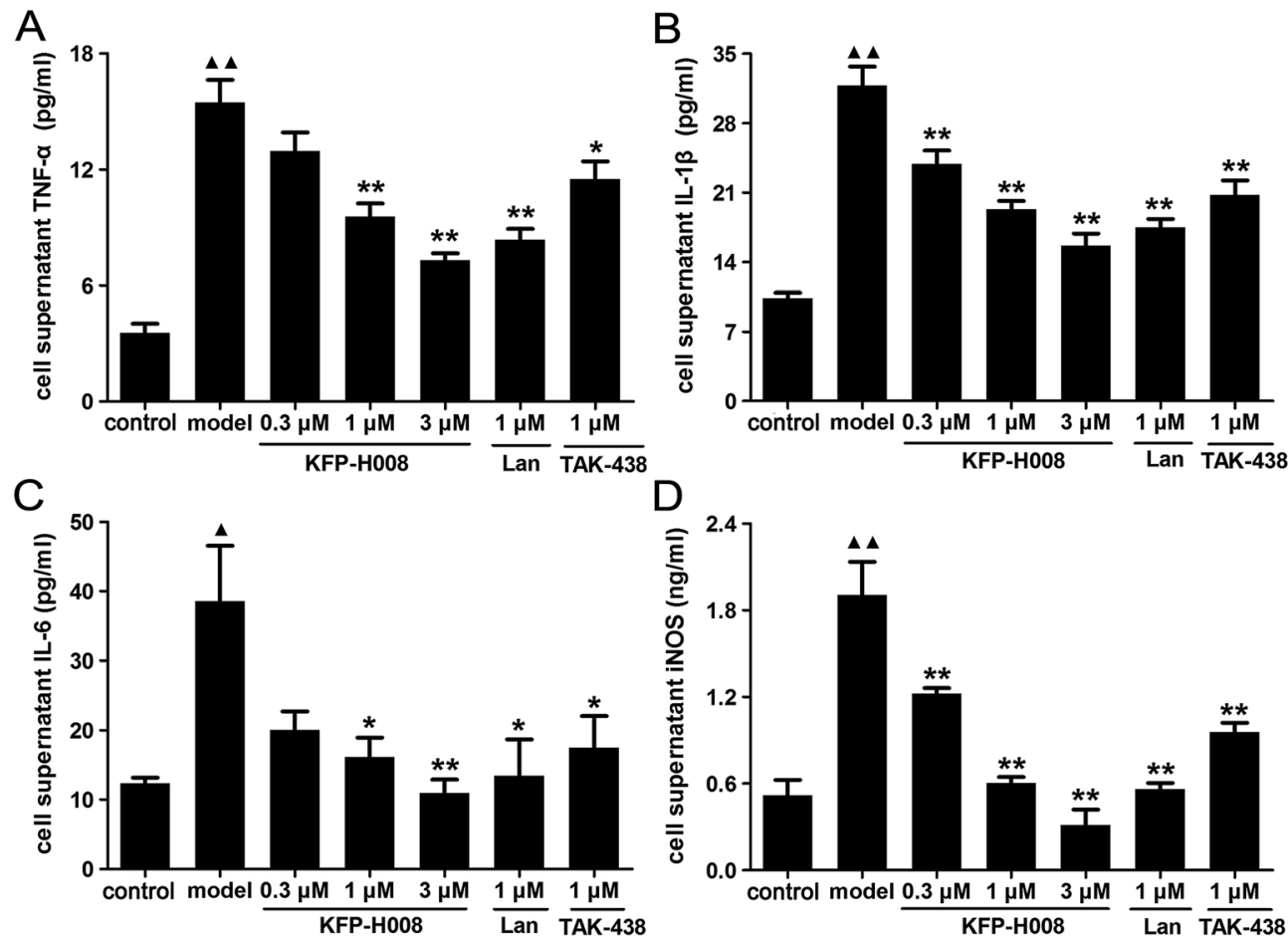

Fig. 7 Effects of KFP-H008 on TNF- $\alpha$ (A), IL-1 (B), IL-6 (C) and iNOS (D) levels in GES-1 cell supernatant after treatment with $5 \%$ ethanol. GES-1 cells were incubated with the vehicle, KFP-H008, lansoprazole and TAK-438 for $24 \mathrm{~h}$, followed by exposure to $5 \%$ ethanol for $24 \mathrm{~h}$. Cell supernatant was collected to test the cytokines levels. $n=3$. Each column represents the mean \pm S.E.M. $\mathbf{\Lambda}, P<0.05, \boldsymbol{\Delta} \boldsymbol{\Delta}, P<0.01$ versus control group. *, $P<0.05, * *, P<0.01$ versus model group.

\section{Discussion}

KFP-H008, a potent P-CAB, has not been reported in treatment of gastric ulcer previously. ${ }^{\mathbf{1 1}}$ In this study, we first reported that KFP-H008 was able to protect the stomach against the gastric lesions caused by ethanol and the underlying mechanism was associated with the antioxidant properties and antiinflammatory status through p38 MAPK/NF-кB pathway.

Alcohol has been reported to inflict hemorrhagic gastric lesions characterized by mucosal friability, cellular exfoliation, extensive submucosal edema and inflammatory cell infiltration. ${ }^{17,18}$ In mice, ethanol consumption can produce oxidative stress and acute inflammatory reaction. ${ }^{19}$ However, oral administration of KFP-H008 effectively reversed ethanolinduced gastric injury in a dose-dependent manner, particularly at the dose of $8 \mathrm{mg} \mathrm{kg}^{-1}$, the \% inhibition was up to $72.81 \%$ (Fig. 1). Apart from gastric ulcer index, KFP-H008 also decreased the histopathological scores, and alleviated microscopic lesions after ethanol consumption (Fig. 2). In GES-1 cells, challenge of ethanol could damage the cell structures and decreased the cell 

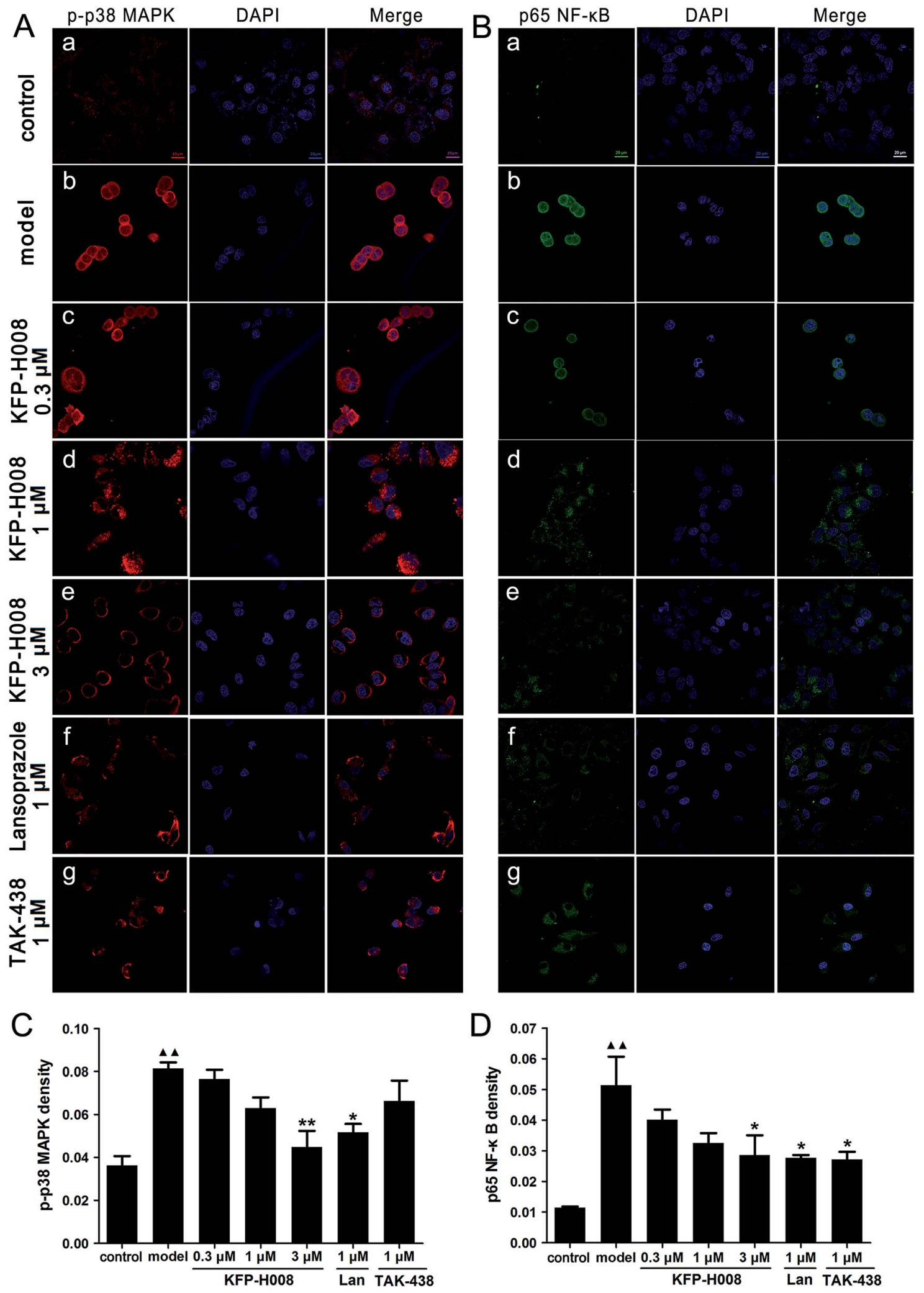

Fig. 8 KFP-H008 inhibited ethanol-induced activation of p38 MAPK/NF- $\kappa B$ signaling in GES-1 cells (magnification $\times 630$ ). Scale bar $=20 \mu$ m. GES-1 cells were incubated with the vehicle, KFP-H008, lansoprazole and TAK-438 for $24 \mathrm{~h}$, followed by exposure to $5 \%$ ethanol for $24 \mathrm{~h}$. (A) Expression of $\mathrm{p}$ p38 MAPK (red) in GES-1 cells were visualized by laser scanning confocal microscopy. The blue staining represents DAPI. (B) Expression of p65 NF- $\kappa B$ (green) in GES-1 cells were visualized by laser scanning confocal microscopy. The blue staining represents DAPI. (a) The control group. (b) Model - 5\% ethanol treatment. (c) $5 \%$ ethanol $+0.3 \mu \mathrm{M} \mathrm{KFP-H008}$. (d) $5 \%$ ethanol $+1 \mu \mathrm{M} \mathrm{KFP-H008}$. (e) $5 \%$ ethanol $+10 \mu \mathrm{M} \mathrm{KFP-H008}$. (f) $5 \%$ ethanol $+1 \mu \mathrm{M}$ lansoprazole. (g) $5 \%$ ethanol $+1 \mu$ M TAK-438. Scale bar $=20 \mu \mathrm{m}$. (C) The mean fluorescence density for p-p38 MAPK. (D) The mean fluorescence density for p65 NF-кB. $n=3$. Each column represents the mean \pm S.E.M. $\boldsymbol{\Delta} \boldsymbol{\Delta}, P<0.01$ versus control group. $*, P<0.05, * *, P<0.01$ versus model group. 
viability. Pre-treated of KFP-H008 significantly increased the cell viability after ethanol consumption (Fig. 6).

There are growing evidences that oxidative stress is an essential factor in the pathogenesis of gastrointestinal mucosal diseases,$^{20}$ and excessive generation of reactive oxygen species (ROS) poses a serious problem to bodily homeostasis and causes oxidative tissue damage. ${ }^{21,22}$ The imbalance of ROS generation and the endogenous antioxidant defense system lead to oxidative stress. ${ }^{23}$ The gastrointestinal tract is a key source of ROS, and ROS is produced in response to cigarette smoking, alcohol consumption, nonsteroidal anti-inflammatory drugs, infections and ischemia-reperfusion radiation. ${ }^{3}$ Lipid peroxidation is triggered by the process of free radical interaction with cell membrane and produce lipid-derived free radicals. MDA is the cytotoxic product of lipid peroxidation, which leads to the cross-linking polymerization of proteins, nucleic acid and other living macromolecules, and arouses the injury of mitochondria and lysosomes. ${ }^{18,24}$ SOD and GSH are important antioxidants that protect gastric mucosal from oxidative damage. SOD mainly converts harmful superoxide anion into less dangerous hydrogen peroxide. ${ }^{25}$ In the mucosa, the GSH system serves as an anti-oxidative barrier, and GSH acts as a reductant and co-factor for some antioxidant enzymes. ${ }^{26}$ In our present study, challenge of ethanol induced a marked oxidative stress, as evidenced by elevated MDA levels and lowered both SOD and GSH levels in the gastric homogenate and serum $(P<0.01$, Fig. 3A-C and F-H). Pre-treatment with KFP-H008 inhibited lipid peroxidation, prevented the depletion of GSH and SOD activities and decreased MDA activity in ethanol-treated mice. And $4 \mathrm{mg} \mathrm{kg}^{-1}$ of KFP-H008 exhibited a stronger effect on the increase of GSH versus the same dose of TAK-438 $(P<0.01$, Fig. 3C). These results indicated that KFP-H008 might have bioprotective effects against ethanol-induced oxidative stress.

Nitric oxide synthase (NOS) is one of the major enzymes that catalyze ROS-generating chemical reactions. NOS is a hemecontaining monooxygenase that generates NO. NO is a weak oxidant, but when it combines with $\mathrm{O}_{2}{ }^{--}$to generate $\mathrm{OONO}^{-}$, it becomes a potent ROS, and disrupts the function of important biological molecules such as DNA, RNA, protein and lipids. ${ }^{27}$ Increased iNOS expression is found in chronic ulcerative colitis and peptic ulcer patients, and NO generated by iNOS has immense effects on the pathophysiological conditions of gastric ulcer. ${ }^{28}$ In our experiments, we observed abundant mucosal lesions, accompanied by the acute rise of NO in ethanol-treated mice $(P<0.01$, Fig. 3D and I). Pre-treatment with KFP-H008 remarkably inhibited the expression of NO in gastric tissues and serum after challenge of ethanol, particularly at the dose of $8 \mathrm{mg} \mathrm{kg}^{-1}$.

Another major source of ROS in ethanol-treated gastric tissue is the infiltration of activated neutrophils. Neutrophil infiltration into gastric mucosal will stimulate the release of several pro-oxidative enzymes and free radicals, which will lead to oxidative burst, and finally promotes the development of acute gastric mucosal lesions. ${ }^{29}$ The activated neutrophils are evaluated by the activity of MPO, which can also be interpreted as a manifestation of anti-inflammatory activity. ${ }^{30}$ In our study, the increased MPO activity represented neutrophil infiltration in the model group $(P<0.01)$, and pre-treatment of KFP-H008 showed a notably inhibitory effect on the accumulation of MPO (Fig. 3E and J). In gastric tissues, the inhibitory action of $4 \mathrm{mg} \mathrm{kg}^{-1}$ KFP-H008 against MPO was stronger than TAK-438 ( $P$ $<0.01$, Fig. 3E). Therefore, it is important to maintain balance between reactive oxygen metabolites and antioxidant defense systems after the occurrence of gastric ulcer.

ROS modulate a number of redox-sensitive signaling pathways including mitogen-activated protein kinase (MAPK), MAPK pathway is the common pathway of intracellular information transmission and is involved in the extracellular signal transduction from the surface to the interior of cell. The activation of MAPK is critical for various toxic substance-induced injury and inflammation including ethanol-induced gastric ulcer in mice. MAPK includes three subtypes: ERK, p38 MAPK and JNK. ERK and p38 MAPK would transfer into the nucleus after stimulation, while JNK might mainly promote apoptosis and dependent on TNF- $\alpha$ pathway. ${ }^{7}$ In this study, we focused on the activation of p38 MAPK in ethanol-induced gastric ulcer, p38 MAPK is one of the most important members that control the inflammatory response. Previous studies have demonstrated that p-p38 MAPK is up-regulated in ethanol-induced gastric ulcer model., ${ }^{71}$ MAPK/NF- $\kappa \mathrm{B}$ is well-known to mediate the expression of proinflammatory cytokines, and has been investigated for oxidative stress mediation in ethanol-induced gastric ulcer. ${ }^{31}$ The phosphorylated p38 MAPK will transfer into the nucleus after the stimulation of upstream signaling cascades (such as tumor necrosis factor, lipopolysaccharide, platelet activating factor and interleukin-1), and then the nuclear transcription factor NF- $\kappa B$ will be activated and regulates the expression of inflammatory genes. ${ }^{32}$ Activation of neutrophils is also related to an up-regulated inflammatory response with increased expression of NF- $\kappa \mathrm{B}$ that controls the generation of pro-inflammatory cytokines including TNF- $\alpha$, IL-1 $\beta$ and IL- $6 .^{33,34}$ Besides cytokine regulation, NF- $\mathrm{KB}$ is also associated with the expression of iNOS and the release of NO. Many evidences proved that NF- $\mathrm{kB}$ could be activated in gastric ulceration. ${ }^{35}$ In this study, we first discovered that the antioxidant and anti-inflammatory properties of KFP-H008 might be related to the down-regulation of p38 MAPK/NF- $\mathrm{BB}$ signaling pathway. Immunohistochemical staining in gastric tissues and immunofluorescence assessments in GES-1 cells showed that challenge of ethanol remarkably promoted the expressions of p-p38 MAPK and p65 NF-кB in the model group, which was significantly reversed by pre-treatment of KFP-H008, especially at the dose of $8 \mathrm{mg} \mathrm{kg}^{-1}$ in vivo $(P<0.01$, Fig. 5) and $3 \mu \mathrm{M}$ in vitro $(P<0.05$, Fig. 8$)$. These results confirmed that KFP-H008 could inhibit the activation of p38 MAPK and the translocation of NF- $\mathrm{kB}$.

It is reported that ROS not only directly damages the cell structures but also promotes the production of proinflammatory cytokines, including TNF- $\alpha$, IL-1 $\beta$ and IL-6. And activation of p38 MAPK or NF-KB can also promote the release of these pro-inflammatory cytokines. TNF- $\alpha$ is involved in the induction of inflammatory lesion and injury in many tissues including gastric mucosa. ${ }^{30}$ Besides, TNF- $\alpha$ serves as an effective stimulator of neutrophils infiltration into gastric mucosal tissues and triggers a cascade of inflammatory reactions. ${ }^{36} \mathrm{IL}-1 \beta$ 
is a pro-inflammatory cytokine produced earlier, which contributes to the development of ethanol-induced gastric mucosal injury, gastric cell damage and the recruitment of other cytokines such as TNF- $\alpha$ and IL-6. ${ }^{7}$ IL-6 is a pleiotropic cytokine that commonly produced at local tissue and is released into circulation. Elevated level of IL-6 activates neutrophils, monocytes and lymphocytes at the inflammatory site, which in turn initiates different oxidative bursts, lysosomal enzyme and toxic metabolites in gastric injury. ${ }^{14}$ Our experimental results showed that the pro-inflammatory cytokines levels were all upregulated significantly in gastric tissues, serum (Fig. 4) and cell supernatant (Fig. 7) due to the challenge of ethanol consumption. However, the inflammatory status were favorably reversed by the pre-treatment of KFP-H008 both in vivo and in vitro, and the effects of KFP-H008 at dose of $8 \mathrm{mg} \mathrm{kg}^{-1}$ worked best. These results demonstrated that KFP-H008 could inhibit inflammatory cytokines levels and exhibited its anti-inflammatory action in ethanol-induced gastric lesions.

In our previous study, we have demonstrated that KFP-H008 is a novel P-CAB and a potential anti-acid drug, which shows a more potent and longer-lasting effect on gastric acid secretion than lansoprazole in rats and heidenhain pouch dogs. The antisecretory mechanism is to block $\mathrm{H}^{+} / \mathrm{K}^{+}$-ATPase. ${ }^{11}$ Besides, we have investigated the toxicity of KFP-H008 before the pharmacodynamics studies and the results demonstrated that KFPH008 will not induce any organ toxicity in long-term toxicity research (data not shown in manuscript). The protective effects of KFP-H008 against gastric ulcer has not been explored before, thus, we chose the ethanol-induced gastric ulcer model in mice to investigate the protective effects and the underlying mechanisms.

In conclusion, KFP-H008 exerted beneficial effects in ethanol-induced gastric ulcer, which were evidenced by biochemical, histopathological, immunohistochemistry and immunofluorescence analysis data. The underlying mechanism may relate to its inhibitory effects on neutrophil infiltration, suppression of the activation of p38 MAPK/NF- $\mathrm{B}$ signaling pathway, and subsequent release of TNF- $\alpha$, IL-1 $\beta$ and IL-6. Further researchers are warranted to explore the clinical application of KFP-H008.

\section{Conflicts of interest}

There are no conflicts to declare.

\section{Acknowledgements}

Financial support for this study was provided by Qinglan Project (No. 2016) and National Major Scientific and Technological Special Project for "Significant New Drugs Development" during the Thirteenth Five-year Plan Period (No. 2016ZX09101031).

\section{References}

1 N. W. Ismail Suhaimy, A. K. Noor Azmi, N. Mohtarrudin, M. H. Omar, S. F. Tohid, M. S. Cheema, L. K. Teh,
M. Z. Salleh and Z. A. Zakaria, Oxid. Med. Cell. Longevity, 2017, 2017, 6542631.

2 L. Ma and J. Liu, J. Ethnopharmacol., 2014, 158(Pt A), 358363.

3 A. Bhattacharyya, R. Chattopadhyay, S. Mitra and S. E. Crowe, Physiol. Rev., 2014, 94, 329-354.

4 O. J. Olatunji, H. Chen and Y. Zhou, Molecules, 2015, 20, 22553-22564.

5 Z. Zhao, S. Gong, S. Wang and C. Ma, Int. Immunopharmacol., 2015, 28, 588-595.

6 W. Li, H. Huang, X. Niu, T. Fan, Q. Mu and H. Li, Toxicol. Appl. Pharmacol., 2013, 272, 21-29.

7 X. Chang, F. Luo, W. Jiang, L. Zhu, J. Gao, H. He, T. Wei, S. Gong and T. Yan, Int. Immunopharmacol., 2015, 28, 604615.

8 X. T. Hu, C. Ding, N. Zhou and C. Xu, Eur. J. Pharmacol., 2015, 754, 115-124.

9 W. Li, X. Wang, H. Zhang, Z. He, W. Zhi, F. Liu, Y. Wang and X. Niu, Int. Immunopharmacol., 2016, 38, 450-459.

10 L. Laine and W. M. Weinstein, Gastroenterology, 1988, 94, 1254.

11 C. Y. Li, M. Su, Y. Y. Yan, L. Zhou, L. Y. Ao, W. R. Fang and Y. M. Li, Eur. J. Pharmacol., 2017, 810, 112-119.

12 W. Li, H. Yao, X. Niu, Y. Wang, H. Zhang, H. Li and Q. Mu, Immunobiology, 2015, 220, 798-806.

13 P. H. Guth, D. Auras and G. Paulsen, Gastroenterology, 1979, 76, 88-93.

14 W. F. Li, D. J. Hao, T. Fan, H. M. Huang, H. Yao and X. F. Niu, Chem.-Biol. Interact., 2014, 208, 18-27.

15 W. C. Zhao, Y. S. Xu, G. Chen, Y. Guo, D. Y. Wang and G. B. Meng, Gastroenterol. Res. Pract., 2017, 2017, 7395032.

16 Y. Hu, N. D. Kodithuwakku, L. Zhou, C. Li, D. Han, W. Fang, J. Liu and Y. Li, Molecules, 2017, 22, 937.

17 S. Verma and V. L. Kumar, Chem.-Biol. Interact., 2016, 257, 46-53.

18 H. Zheng, Y. Chen, J. Zhang, L. Wang, Z. Jin, H. Huang, S. Man and W. Gao, Chem.-Biol. Interact., 2016, 250, 68-77. 19 A. Jaccob, J. Intercult. Ethnopharmacol., 2015, 4, 90.

20 I. A. Ibrahim, M. A. Abdulla, M. Hajrezaie, A. Bader, N. Shahzad, S. S. Al-Ghamdi, A. S. Gushash and M. Hasanpourghadi, Drug Des., Dev. Ther., 2016, 10, 93-105. 21 N. Nazarbahjat, F. A. Kadir, A. Ariffin, M. A. Abdulla, Z. Abdullah and W. A. Yehye, PLoS One, 2016, 11, e0156022. 22 K. P. Lee, N. H. Choi, G. W. Sudjarwo, S.-H. Ahn, I.-S. Park, S.-R. Lee and H. Hong, J. Med. Food, 2016, 19, 127-132.

23 R. N. El-Naga, Chem.-Biol. Interact., 2015, 242, 317-326.

24 P. Chen, Y. Shen, H. Shi, X. Ma, B. Lin, T. Xiao, F. Wu, J. Zhu, Z. Li, J. Xiao, X. Li, H. Zhang and F. Geng, Chem.-Biol. Interact., 2016, 75-83.

25 M. F. Halabi, R. M. Shakir, D. A. Bardi, N. S. Alwajeeh, A. Ablat, P. Hassandarvish, M. Hajrezaie, A. Norazit and M. A. Abdulla, PLoS One, 2014, 9, e95908.

26 X. Mei, D. Xu, S. Xu, Y. Zheng and S. Xu, Chem.-Biol. Interact., 2012, 197, 31-39.

27 J. V. Medeiros, G. G. Gadelha, S. J. Lima, J. A. Garcia, P. M. Soares, A. A. Santos, G. A. Brito, R. A. Ribeiro and M. H. Souza, Br. J. Pharmacol., 2008, 153, 721-727. 
28 C. Yu, X. T. Mei, Y. P. Zheng and D. H. Xu, Eur. J. Pharmacol., 2014, 740, 329-336.

29 T. Chen, W. Jiang, H. Zhang, X. You, M. Liu, L. Wang, P. Xiang, L. Xu, D. Zheng, X. Zhang, H. Ji, K. Hao and T. Yan, RSC Adv., 2016, 6, 20081-20088.

30 H. H. Arab, S. A. Salama, H. A. Omar, e. S. A. Arafa and I. A. Maghrabi, PLoS One, 2015, 10, e0122417.

31 J. Liu, F. Wang, H. Luo, A. Liu, K. Li, C. Li and Y. Jiang, Int. Immunopharmacol., 2016, 30, 179-187.

32 S. Hui and W. Fangyu, Biomed. Pharmacother., 2017, 85, 592600.
33 H. Mustonen, P. Puolakkainen, E. Kemppainen, T. Kiviluoto and E. Kivilaakso, Dig. Dis. Sci., 2009, 54, 928-936.

34 J. M. Kim, S. H. Kim, S. H. Ko, J. Jung, J. Chun, N. Kim, H. C. Jung and J. S. Kim, Am. J. Physiol.: Gastrointest. Liver Physiol., 2013, 304, G193.

35 S. A. El-Maraghy, S. M. Rizk and N. N. Shahin, Chem.-Biol. Interact., 2015, 229, 26-35.

36 J. Yao, Evid. Based Complement. Alternat. Med., 2015, 2015, 647283. 